\title{
Low-field thoracic magnetic stimulation increases peripheral oxygen saturation levels in coronavirus disease (COVID-19) patients: a single-blind, sham-controlled, crossover study Saul M Dominguez-Nicolas ${ }^{1,2}$, Elias Manjarrez ${ }^{3}$ \\ ${ }^{1}$ Centro de Investigación de Micro y Nanotecnología, Universidad Veracruzana, Calzada \\ Ruiz Cortines 455 Boca del Rio, Veracruz 94294, México \\ ${ }^{2}$ Facultad de Ingeniería Eléctrica y Electrónica, Universidad Veracruzana, Calzada Ruiz Cortines 455, Boca del Rio, Veracruz 94294, México \\ ${ }^{3}$ Instituto de Fisiología, Benemérita Universidad Autónoma de Puebla, 14 Sur 6301, Colonia San Manuel, Apartado Postal 406, CP 72570, Puebla, Puebla, México.
}

Running title: LF-ThMS improves SpO2 levels in a single session

Number of words: Text 5661, abstract (215), introduction (625), discussion (1373)

Number of text pages: 25

Number of Figures: 4

Number of Tables: 3

Trial registration: ClinicalTrials.gov Identifier: NCT04895267

\section{${ }^{*}$ Corresponding Authors:}

\section{Dr. Saul M Dominguez-Nicolas}

Centro de Investigación de Micro y Nanotecnología, Universidad Veracruzana

Calzada Ruiz Cortines 455 Boca del Rio, Veracruz 94294, Mexico

saudominguez@uv.mx

\section{Dr. Elias Manjarrez}

Instituto de Fisiología, Benemérita Universidad Autónoma de Puebla.

14 sur 6301, Col. San Manuel A.P. 406, C.P. 72570

Puebla, Pue., México

Tels.: +5222-22-29-5500 Ext 7326, Fax: +5222-22-33-4511

eliasmanjarrez@gmail.com

elias.manjarrez@correo.buap.mx

Keywords: LF-ThMS, SARS-CoV-2, oxygen saturation, virus spike protein, thorax, lungs, pulsed magnetic stimulation, $\mathrm{SpO} 2$, hyperthermia, magnetic therapy, virus inactivation, COVID-19 
medRxiv preprint doi: https://doi.org/10.1101/2021.05.21.21256456; this version posted May 25, 2021. The copyright holder for this preprint (which was not certified by peer review) is the author/funder, who has granted medRxiv a license to display the preprint in perpetuity. It is made available under a CC-BY-NC-ND 4.0 International license .

May 21th 2021

\section{Abstract}

The severe acute respiratory syndrome coronavirus-2 (SARS-CoV-2) may cause low oxygen saturation (SpO2) and respiratory failure in coronavirus disease (COVID-19) patients. Hence the increase of SpO2 levels could be crucial for the quality of life and recovery of these patients. Here we introduce an electromagnetic device termed lowfield thoracic magnetic stimulation (LF-ThMS) system. This device was designed to non-

52 invasively deliver a pulsed magnetic field from 100 to $118 \mathrm{~Hz}$ and 10.5 to $13.1 \mathrm{mT}$ (i.e.,

53105 to 131 Gauss) to the dorsal thorax. We show that these frequencies and magnetic

54 flux densities are safe for the patients. We also present a proof-of-concept that a single session of LF-ThMS applied for 30 minutes to the dorsal thorax of 17 COVID-19 patients significantly increases their SpO2 levels. We designed a single-blind, sham-controlled,

57 crossover study on 5 COVID-19 patients who underwent two sessions of the study (real and sham LF-ThMS) and 12 COVID-19 patients who underwent only the real LF-ThMS.

59 We found a statistically significant correlation between magnetic flux density, frequency, or temperature associated with the real LF-ThMS and SpO2 levels in all COVID-19 patients. However, the five patients of the sham-controlled study did not exhibit a significant change in their $\mathrm{SpO} 2$ levels during sham stimulation. All the patients did not present adverse events after the LF-ThMS intervention. 
medRxiv preprint doi: https://doi.org/10.1101/2021.05.21.21256456; this version posted May 25, 2021. The copyright holder for this preprint (which was not certified by peer review) is the author/funder, who has granted medRxiv a license to display the preprint in perpetuity. It is made available under a CC-BY-NC-ND 4.0 International license .

May 21th 2021

\section{Introduction}

Although recent studies about the structure and function of SARS-CoV-2 may

71 help develop new targeted treatments against COVID-19, there is still not a universally

72 approved treatment for this sickness [1,2]. For instance, some pharmacological

73 treatments include the controversial use of azithromycin, ivermectin, oseltamivir,

74 remedesivir, favipiravir, tocilizumab, ribavirin, lopinavir, interferon $\beta-1 b$,

75 lopinavir/ritonavir, hydroxychloroquine, or chloroquine phosphate (for review, see

$76[1,3,4])$. Many of them are based mainly on case studies, prospective, or retrospective

77 observational studies, with a low number of randomized controlled trials and low quality

78 of study design to guarantee their efficacy and safety [5]. Moreover, in severe cases,

79 many countries employ empiric antimicrobial therapy, mechanical ventilation,

80 convalescent plasma therapy, or combinations of antiviral and anti-inflammatory drugs

81 [6,7]. Because fever and acute respiratory failure are common symptoms, the

82 management of these patients includes antipyretics and oxygen therapy to increase

83 SpO2 levels during respiratory distress. Hence the development of new methods to

84 increase SpO2 levels in COVID-19 patients could become a potential complement of

85 oxygen masks, ventilators, or other modalities to improve oxygenation.

This study aimed to present a proof-of-concept that a 30 minutes single-session

87 of dorsal LF-ThMS can be employed to increase SpO2 levels in COVID-19 patients

88 significantly. We hypothesized that the variables associated with LF-ThMS, as

89 frequency, magnetic flux density, and temperature in the dorsal thorax, might be

90 correlated to SpO2 levels in these patients. Our proof-of-concept research could be

91 helpful to design future randomized controlled trials intended to develop plausible LF-

92 ThMS treatments in the successful management of these patients. 
medRxiv preprint doi: https://doi.org/10.1101/2021.05.21.21256456; this version posted May 25, 2021. The copyright holder for this preprint (which was not certified by peer review) is the author/funder, who has granted medRxiv a license to display the preprint in perpetuity. It is made available under a CC-BY-NC-ND 4.0 International license .

May 21th 2021

We acknowledge that several magnetic field interventions are controversial, but others are gaining an excellent reputation as the transcranial magnetic stimulation. This controversy could be due to the low quality of study designs alongside the exaggerated promotion of alternative therapies intended only for lucrative practices. Therefore, to avoid misinterpretations with our research, we included a single-blind, sham-controlled, crossover study on 5 COVID-19 patients who underwent two sessions of the study (real and sham LF-ThMS) and 12 COVID-19 patients who underwent only the real LF-ThMS. Moreover, we applied LF-ThMS in a short time range, i.e., in a 30 minutes single101 intervention to measure SpO2 values. In this form, we avoided confounding factors related to the spontaneous recovery by natural immunity, common in many COVID-19 patients several days after the contagion.

Regarding safety, our LF-ThMS device applied to the dorsal thorax produces lowintensity magnetic flux densities in a safe range of 10.5 to $13.1 \mathrm{mT}$ at 100 to $118 \mathrm{~Hz}$.

106 Such magnetic fields are within the frequency range of extremely low-frequency (0-300 $107 \mathrm{~Hz}$ ) magnetic fields (ELF-MFs) to study the interaction between ELF-MFs and neuronal 108 systems $[8,9,10]$. Our LF-ThMS device also produces heat with a safe temperature range from 27.5 to $44{ }^{\circ} \mathrm{C}$, consistent with the well-known tolerance of the isolated and 110 perfused dog lung to hyperthermia in this temperature range [11,12]. Rickaby et al. 111 (1991) [11] found that temperatures below $44.4{ }^{\circ} \mathrm{C}$ for two hours had no detectable 112 influence on the following measured variables of lung weight, extravascular water, 113 vascular volume, serotonin uptake, urea permeability, surface area product, perfusion 114 pressure, and lung compliance. In line with such findings, Cowen et al. (1992) [12] 115 confirmed that the isolated dog lung with perfusion was tolerant to hyperthermia up to 
medRxiv preprint doi: https://doi.org/10.1101/2021.05.21.21256456; this version posted May 25, 2021. The copyright holder for this preprint (which was not certified by peer review) is the author/funder, who has granted medRxiv a license to display the preprint in perpetuity. It is made available under a CC-BY-NC-ND 4.0 International license .

May 21th 2021

about $44{ }^{\circ} \mathrm{C}$ for 1 hour. Other studies claim that hyperthermia in this range is beneficial

117 and enhances the immune response $[13,14,15]$.

Our results demonstrate that LF-ThMS locally applied to the dorsal thorax of

COVID-19 patients is safe and valuable to significantly increase SpO2 levels during a single LF-ThMS intervention of 30 minutes. This is in line with models predicting the electrical [16] or thermal inactivation of SARS-CoV-2 [17] in the environment or with the hypothesis that hydro-thermotherapy or photobiomodulation could help in the treatment of COVID-19 patients $[18,19]$.

\section{Materials and methods}

Study design

We designed a single-blind, sham-controlled, crossover study on 5 COVID-19 subjects who underwent two sessions of the study (sham or real LF-ThMS) and 12 COVID-19 subjects who underwent only the real LF-ThMS stimulation. The study was performed following the Declaration of Helsinki and approved by a local ethics committee from the Benemérita Universidad Autónoma de Puebla, Mexico (protocol:

131 Oficio No. SIEP/C.I./065A/2020, book number: 2, sheet number: 133, registration 132 number: 818, date: July 3, 2020). The study was registered in ClinicalTrials.gov 133 (Identifier: NCT04895267). All subjects voluntarily participated with full understanding and signed informed consent. The SPIRIT-Checklist is included as a supplementary file.

\section{Patients}

We applied LF-ThMS on the dorsal thorax to 17 patients (25-81 years of age) who were selected according to the following criteria. The inclusion criteria were: 1)

138 Adult patients diagnosed with mild to moderate COVID-19 disease without pneumonia. 139 The COVID-19 disease severity was interpreted by the clinical assessment of 
medRxiv preprint doi: https://doi.org/10.1101/2021.05.21.21256456; this version posted May 25, 2021. The copyright holder for this preprint (which was not certified by peer review) is the author/funder, who has granted medRxiv a license to display the preprint in perpetuity. It is made available under a CC-BY-NC-ND 4.0 International license .

May 21th 2021

physicians, who followed the interim guidance for the clinical management of COVID-19

141 from the world health organization, May 27, 2020. 2) Patients with a SpO2 level less or

142 equal to $90 \%$, exhibiting difficulty breathing, but not intubated patients. The physicians

143 selected this set of patients because they had a low risk of developing a severe clinical

144 condition with pneumonia or with a chance of being intubated. 3) Patients with similar

145 pharmacological treatment against COVID-19. All the patients were medicated by 146 physicians in respiratory medicine with Azithromycin (500 mg), Ivermectin (6 mg), and

147 Oseltamivir $(75 \mathrm{mg})$. The most prevalent comorbidities in these patients were diabetes 148 and hypertension.

The exclusion criteria were as follows: 1) COVID-19 patients with acute

150 respiratory failure requiring urgent intubation, 2) COVID-19 patients with impaired 151 consciousness or during pregnancy, 3) patients with metallic implants in the thorax, 152 abdomen or arms, or electronic medical devices such as pacemakers, and 4) children.

The criteria for discontinuing the LF-ThMS intervention were the participant 154 request, $\mathrm{SpO} 2$ decrease, or any discomfort reported by the patient during the 155 intervention. The strategy for achieving adequate participant enrolment to reach target sample size was the description of favorable results obtained from other patients

157 Low-field thoracic magnetic stimulation (LF-ThMS) device pending by Dominguez-Nicolas SM, 2020) to modulate alternating current in a coil pair

160 to generate low magnetic flux densities and magnetic hyperthermia for COVID-19 161 patients. Previous patents and experimental studies also induce magnetic hyperthermia 162 [20-23], but they reach up to $71^{\circ} \mathrm{C}\left(160^{\circ} \mathrm{F}\right)$, not suitable for our application. Instead, we 
medRxiv preprint doi: $\mathrm{https}: / /$ doi.org/10.1101/2021.05.21.21256456; this version posted May 25, 2021. The copyright holder for this preprint (which was not certified by peer review) is the author/funder, who has granted medRxiv a license to display the preprint in perpetuity. It is made available under a CC-BY-NC-ND 4.0 International license .

May 21th 2021

164 magnetic flux density levels up to $44^{\circ} \mathrm{C}$ and $13.1 \mathrm{mT}$ for its safe use in the dorsal thorax of COVID-19 patients. In this form, we avoided harmfulness or adverse effects. The LFThMS device consisted of a virtual instrument, a PCI-DAS6031 acquisition board (Measurement Computing), an electronic board for the coupling between the digital signal and power, a power source of $0-15 \mathrm{Vcc}$, and $6-30 \mathrm{~A}$, and two rings made of coils to generate LF-ThMS. We used $1.7 \mathrm{~cm}$ of cotton cloth disk between the LF-ThMS rings and the patient's skin to allow homogeneous heat diffusion.

To generate the magnetic field, we used alternating current from 100 to $118 \mathrm{~Hz}$ with a peak amplitude of $8 \mathrm{~A}$, polarized at $12 \mathrm{Vcc}$ with a regulated power source of $0-15$ Vcc and 6-30 A. We fabricated a couple of rings for LF-ThMS with an internal diameter of $9.5 \mathrm{~cm}$ and 130 turns. The LF-ThMS device emitted magnetic flux densities in the range of 10.5 to $13.1 \mathrm{mT}$. These were calculated theoretically with the Biot-Savart law and physically with a magnetic field sensor (475 DSP Gaussmeter, Lakeshore). We also used a thermocouple sensor (model NTC 10k) for monitoring temperature changes due to the LF-ThMS. Both the Gaussmeter and thermocouple sensors were helpful to calibrate magnetic flux densities and temperatures in a safe range (Table 1).

The main electronic components of the LF-ThMS device consist of a power relay $\mathrm{RL}$ of two poles, a $12 \mathrm{Vcc}$ coil, silver alloy contacts of Vcc/10A or $250 \mathrm{Vca} / 10 \mathrm{~A}, \mathrm{Q} \mathrm{NPN}$ 2N2222 transistor, $10 \mathrm{k} \Omega$ resistance at 0.25 Watts, and a D IN4007 semiconductor diode. We also employed a PCI-DAS6031 board to energize the RL at $10 \mathrm{Vcc}$ and a virtual instrument developed in Delphi Borland 7. Figure 1 shows the electronic circuit of our LF-ThMS device, and Table 1 shows the frequency, magnetic flux density, and temperature associated with the LF-ThMS during a 30 minutes single session. 
medRxiv preprint doi: https://doi.org/10.1101/2021.05.21.21256456; this version posted May 25, 2021. The copyright holder for this preprint (which was not certified by peer review) is the author/funder, who has granted medRxiv a license to display the preprint in perpetuity. It is made available under a CC-BY-NC-ND 4.0 International license .

May 21th 2021

\section{LF-ThMS protocol}

The LF-ThMS was locally applied on the dorsal thorax while the patients were kept in a prone position. The LF-ThMS intensity was successively increased every 5 min during a single session of $30 \mathrm{~min}$, following the values of frequency, magnetic flux density, and temperature indicated in Table 1. The protocol for the proof of concept consisted of a single LF-ThMS session of 30 minutes, although other daily sessions in three or four other consecutive days were applied to verify its reproducibility. The rationale of presenting here only the results from the first session was to evaluate the hypothesis that SpO2 levels in COVID-19 patients are significantly correlated with the magnetic flux density and temperature during 30 minutes of LF-ThMS intervention (see discussion section).

Figure 2A illustrates anatomical landmarks and coordinates of the LF-ThMS rings. We positioned the center of these LF-ThMS rings using palpable skeletal landmarks. We employed the spinous process of C7 (i.e., vertebra prominens) as zero landmarks (see a gray circle in Figure 2A). The center of these rings was positioned $8.5 \mathrm{~cm}$ below this landmark and bilaterally $\pm 6 \mathrm{~cm}$ on the dorsal thorax (see black arrows in Figure 2A).

The device allowed a gradual increase in the frequency, magnetic flux density, and temperature, as illustrated in Figure 2B, 2C, and 2D, respectively. The patients rested for three hours after the session, and they did not report any discomfort during or after the magnetic stimuli. In contrast, they felt more comfortable, mainly because the LF-ThMS improved their breathing from the first minutes of the session. We checked on the health conditions of all the patients after receiving the LF-ThMS. In addition, in 11/17 patients, we monitored their SpO2 levels at the end of six months (see Results section). 
medRxiv preprint doi: https://doi.org/10.1101/2021.05.21.21256456; this version posted May 25, 2021. The copyright holder for this preprint (which was not certified by peer review) is the author/funder, who has granted medRxiv a license to display the preprint in perpetuity. It is made available under a CC-BY-NC-ND 4.0 International license .

May 21th 2021

\section{Sham stimulation}

The coils were positioned in the same coordinates for sham exposure, but the

213 pulse generator was not turned on. Subjects were blinded for the real LF-ThMS or sham

214 stimulation conditions.

Peripheral oxygen saturation (SpO2) level, magnetic flux density, and temperature

The peripheral oxygen saturation (SpO2) level was monitored with a conventional ThMS session. Thus, seven SpO2 measurements, including the control (time zero, at $27.5^{\circ} \mathrm{C}$ and $0 \mathrm{mT}$, without LF-ThMS and compensating the terrestrial magnetic field), were obtained per subject. In this way, we were able to quantify the repeatability of effects of LF-ThMS through the study in different patients.

We analyzed the statistical differences among the SpO2 levels related to each $P>0.05$ ) with homogeneity of variances, we used parametric one-way repeatedmeasures ANOVA under the null hypothesis that the dependent variables "SpO2 levels" were the same across the different LF-ThMS intensities. We also employed Mauchly's test to verify that the assumption of sphericity was not violated. We performed a pairwise post hoc test using the corrected Bonferroni adjustment. All effects are reported as significant if $p<0.001$. 
medRxiv preprint doi: https://doi.org/10.1101/2021.05.21.21256456; this version posted May 25, 2021. The copyright holder for this preprint (which was not certified by peer review) is the author/funder, who has granted medRxiv a license to display the preprint in perpetuity. It is made available under a CC-BY-NC-ND 4.0 International license .

May 21th 2021

ThMS intervention. The sample size was $n=35$ SpO2 measurements during seven LF-

236 ThMS levels (including the control) in five patients of the sham-controlled experiment

237 and $\mathrm{n}=119 \mathrm{SpO} 2$ values in another 12 patients. The correlation coefficient was

238 calculated for $n-2=33$ or $n-2=117$ degrees of freedom (DF), and the correlation was reported as significant if $p<0.001$. Data were expressed as mean \pm standard deviation in the main text and the figures.

\section{Results}

We measured the SpO2 level for all the patients before the LF-ThMS intervention.

243 We found that COVID-19 patients presented similar symptoms. On the first day of

244 magnetic stimulation, we found that the patients experienced difficulty breathing with a 245 low SpO2 level of $86.6 \pm 2.2 \%$ ( $\mathrm{N}=17$ patients), consistent with COVID-19 signs and 246 breathlessness symptoms. However, we found that during the LF-ThMS, the patients 247 exhibited a gradual increase in their SpO2 levels. No adverse events or discomfort 248 sensations were reported during or after the LF-ThMS. LF-ThMS

252 levels during sham stimulation (five subjects, Figure 3A). We performed parametric oneway repeated-measures ANOVA to examine statistical significance between $\mathrm{SpO} 2$

254 levels during the sham stimulation in all the patients. The differences in the mean values 255 among the sham groups are not great enough to exclude the possibility that the 256 difference is due to random sampling variability, i.e., there is no statistically significant 257 difference $[F=0.165, D F=6, p=0.984]$. 
medRxiv preprint doi: $\mathrm{https}: / /$ doi.org/10.1101/2021.05.21.21256456; this version posted May 25, 2021. The copyright holder for this preprint (which was not certified by peer review) is the author/funder, who has granted medRxiv a license to display the preprint in perpetuity. It is made available under a CC-BY-NC-ND 4.0 International license .

May 21th 2021

However, during the real LF-ThMS, we observed statistically significant changes in SpO2 levels in response to real LF-ThMS in 5 COVID-19 subjects who previously underwent sham stimulation (green triangles and green line; Figure 3B) and in the other 12 COVID-19 subjects who underwent only the real LF-ThMS (orange circles and gray line; Figure 3B). We performed parametric one-way repeated-measures ANOVA to examine statistical significance between groups: "control SpO2 levels" and "SpO2 levels during the LF-ThMS interventions" in all the patients (17 subjects). The differences in the mean values among the treatment groups were more significant than would be expected by chance $[F=13.872, D F=6, p<0.001]$. The post hoc test indicated that the significant main effect exhibited significant differences $(p<0.001)$ between the "control SpO2 levels" and the "SpO2 levels obtained after 20 min of LF-ThMS interventions" (Table 2). In contrast, no statistically significant differences $(p>0.05)$ were found before 20 min of LFThMS interventions (Table 2). This indicates that the LF-ThMS at the frequency and magnetic flux density employed produces changes in SpO2 levels only after 20 minutes of LF-ThMS application.

Correlations among the frequency, magnetic flux density, and temperature elicited by the LF-ThMS versus the SpO2 levels of COVID -19 patients

In the controlled study, we also examined whether SpO2 levels exhibited correlations with the sham session time. We observed no statistically significant correlation between SpO2 levels and session time in the sham condition (Pearson's 278 product-moment correlation coefficient $r=0.07, D F=33, p=0.65$, gray regression line, 279 Figure 3A). However, we obtained a statistically significant correlation between SpO2 280 values and session time in the real LF-ThMS applied to the same five subjects that 
medRxiv preprint doi: https://doi.org/10.1101/2021.05.21.21256456; this version posted May 25, 2021. The copyright holder for this preprint (which was not certified by peer review) is the author/funder, who has granted medRxiv a license to display the preprint in perpetuity. It is made available under a CC-BY-NC-ND 4.0 International license .

May 21th 2021

281

282

283

284

285

286

287

288

289

290

291

292

293

294

295

296

297

298

299

300

301

302

303

previously underwent the sham stimulation (Pearson's product-moment correlation coefficient $r=0.81$, DF=33, $p<0.001$, green regression line, Figure 3B).

Finally, we examined whether the SpO2 levels exhibited correlations with the LFThMS session time, frequency, magnetic flux density, and temperature for all the patients. Figure 3B and Figures 4A, 4B, and 4C show significant correlations between these measurements. Pearson's product-moment correlation method was used to test for significant correlations. We obtained a $p<0.001$ with 117 or 100 degrees of freedom and correlation coefficients $r=0.64,0.58,0.55$, and 0.64 , as indicated (see Figure $3 B$, and Figures 4A, 4B, and $4 \mathrm{C}$ ). These statistically significant results suggest that the changes in SpO2 levels during a 30 min LF-ThMS session are related to their associated variables: frequency, magnetic flux density, and temperature. These findings provide support to our hypothesis.

\section{Adverse events}

We did not find adverse effects during or after the LF-ThMS intervention. We also made a follow-up on the health conditions of all the patients. We found that five days after successive LF-ThMS sessions, the mean SpO2 level was $98.3 \pm 0.7 \%$ for 17 patients (Table 3). We also found a mean SpO2 level of $98.4 \pm 0.8 \%$, for 11 patients, six months after the LF-ThMS intervention (Table 3). Such normal SpO2 levels indicate that the LF-ThMS did not produce adverse events in the oxygen saturation. In the follow-up on the general health conditions after five days or six months, the physicians confirmed that the patients did not exhibit any adverse event or secondary effect after the LFThMS intervention. These findings indicate that 30 minutes of LF-ThMS intervention on the dorsal thorax of COVID-19 patients is safe at the frequencies, magnetic flux 
medRxiv preprint doi: https://doi.org/10.1101/2021.05.21.21256456; this version posted May 25, 2021. The copyright holder for this preprint (which was not certified by peer review) is the author/funder, who has granted medRxiv a license to display the preprint in perpetuity. It is made available under a CC-BY-NC-ND 4.0 International license .

May 21th 2021

304 305

densities, and temperatures of 100 to $128 \mathrm{~Hz}, 10.5$ to $13.1 \mathrm{mT}$, and 27.5 to $44{ }^{\circ} \mathrm{C}$, respectively.

\section{Discussion}

We found statistically significant correlations between SpO2 levels in COVID-19 patients and LF-ThMS variables in a time range of 30 minutes, but not in the shamcontrolled study.

\section{Reproducibility}

Our findings were reproducible in all the patients in a time range of 30 minutes of LF-ThMS intervention. Interestingly, our results were also reproducible in three or four other subsequent sessions. However, we did not present such data because the changes could be associated with an ongoing daily recovery of the patients due to unknown immune mechanisms and not necessarily due to the daily LF-ThMS intervention. Hence, future studies of randomized controlled trials will be necessary to examine the potential use of this LF-ThMS application as therapy during consecutive daily sessions in covid-19 patients. Therefore, the principal value of our results is that in the sham-controlled study, we found a reproducible and significant correlation between LF-ThMS associated variables and $\mathrm{SpO} 2$ levels in a short time range of 30 minutes.

\section{Possible interference of LF-ThMS hyperthermia with the virus-host protein} interactions

It is well known that several viral protein complexes mediate the entry and replication of SARS-CoV-2 into the cells, manipulating the host mRNA translation, subsequent viral protein production, antivirus immunity, and inflammation response to inducing lung infection and pneumonia. Specifically, this pathogen is a single-stranded RNA virus with gene fragments expressing structural and nonstructural proteins [24-26]. 
medRxiv preprint doi: https://doi.org/10.1101/2021.05.21.21256456; this version posted May 25, 2021. The copyright holder for this preprint (which was not certified by peer review) is the author/funder, who has granted medRxiv a license to display the preprint in perpetuity. It is made available under a CC-BY-NC-ND 4.0 International license .

May 21th 2021

Several viral protein complexes are involved in the entry and replication of this virus into

329 the cells; for instance, the virus spike (S) protein and the nonstructural protein 1 (nsp1).

330 The first one mediates cell entry via binding with angiotensin-converting enzyme 2 in

331 host cells (AEC2), and the second one, the crucial virus-host interactions [27,28].

332 Because there is evidence that a temperature increase of tissue can affect proteins and

333 enhance the immune response $[14,15]$, it is tempting to speculate that hyperthermia 334 produced by the LF-ThMS may acutely interfere with these viral proteins and improve 335 respiratory function.

336 Possible interference of LF-ThMS magnetic flux with the virus-host electrical interactions

Another possibility is that the magnetic stimuli could also directly interfere with the positively charged site in the SARS-CoV-2 spike protein, disturbing the electrical binding between the virus protein and the negatively charged human-cell receptors. This is 341 consistent with recent simulation studies, reporting a positively charged site (called polybasic cleavage site) positioned 10 nanometers from the actual binding site on the SARS-CoV-2 spike protein [29]. These authors found that the positively charged site 344 allows strong bonding between the virus protein and the negatively charged cell 345 receptors. In their simulation, Qiao and Olvera de la Cruz [29] designed a negatively 346 charged molecule to bind to the positively charged cleavage site, with the idea that blocking this site inhibits the virus from bonding to the host cell [29]. Therefore, it is also

348 tempting to speculate that interfering with the electrostatic interaction during the binding 349 action of the SARS-CoV-2 spike protein and the ACE2 receptors, or the nsp1 could 350 mitigate the viral infection. This possible mode of action of the LF-ThMS is also 
medRxiv preprint doi: https://doi.org/10.1101/2021.05.21.21256456; this version posted May 25, 2021. The copyright holder for this preprint (which was not certified by peer review) is the author/funder, who has granted medRxiv a license to display the preprint in perpetuity. It is made available under a CC-BY-NC-ND 4.0 International license .

May 21th 2021

consistent with the claim that electrostatic precipitators are also valuable for eliminating

352 airborne virus particles [30,31].

Possible interference of LF-ThMS hyperthermia with the immune response and interferon activity

Another mechanism by which the LF-ThMS up to $44{ }^{\circ} \mathrm{C}$ could improve SpO2 levels in COVID-19 patients is the enhanced immune response due to the dorsal thorax's increased temperature during the intervention. This is consistent with reports that hyperthermia potentiates the immune response against cancer through immune cells' activation $[15,32,33]$. Some of the immune cells activated by hyperthermia are the natural killer cells, dendritic cells, and cytotoxic T-lymphocytes, which alter the cellsurface molecules on cancer cells, modifying adhesion molecules on immune cells and endothelial cells [32].

Previous studies claimed that Interferons could have a potential role in treating COVID-19 patients [34]. However, recent investigations demonstrated that the SARS[35]. This means that interferons could help or damage, depending on the infection stage for each COVID-19 patient. In this context, we suggest that LF-ThMS should be applied at the first stages of the COVID-19 infection to enhance interferon activity by an increased temperature, in which the interferons may confer an antiviral state on cells.

\section{Possible interference of LF-ThMS in inflammation and cytokine storm}

Finally, because the inflammation and cytokine storm are the main factors

372 contributing to breathing, ventilation, and oxygenation, in COVID-19 patients, it will be 373 necessary to examine in future studies whether the LF-ThMS has an impact on these 374 factors. 
medRxiv preprint doi: https://doi.org/10.1101/2021.05.21.21256456; this version posted May 25, 2021. The copyright holder for this preprint (which was not certified by peer review) is the author/funder, who has granted medRxiv a license to display the preprint in perpetuity. It is made available under a CC-BY-NC-ND 4.0 International license .

May 21th 2021

375

376

377

378

379

380

381

382

383

384

385

386

387

388

389

390

391

392

393

394

395

396 397 of depth.

\section{Advantages and limitations}

The first potential advantage of the thoracic LF-ThMS is that the subjects did not require oxygen therapy with face masks, mainly because during the LF-ThMS session, the patients significantly increased their SpO2 levels 20 minutes after the LF-ThMS $(p<0.001$, Table 2). The second advantage is that the device for LF-ThMS is easy to reproduce, and the electronic components are not expensive. It may be possible that several pulsed electromagnetic field devices employed in physical therapy worldwide could be adapted to emit magnetic fields at 100 to $118 \mathrm{~Hz}, 10.5$ to $13.1 \mathrm{mT}$ (105 to 131 Gauss), and 27.5 to $44{ }^{\circ} \mathrm{C}$.

The main limitations of our study are the following. We do not know the physiological mechanisms through which the administered LF-ThMS during a $30 \mathrm{~min}$ session improved SpO2 levels in COVID-19 patients. We also did not explore whether the LF-ThMS intervention enhances the patients' immune response or whether it impacts the electrical charges of the SARS-CoV-2 viral proteins or the inflammation and cytokine storm in COVID-19 patients. However, our study will motivate future investigations in this research field.

Another limitation of our study is that it will be necessary to know the real temperature in the lungs associated with variations in temperature of the external dorsal thorax by LF-ThMS. It is expected that such temperatures should be lower than those on the external dorsal thorax due to the diffusion processes of heat transfer occurring in the skin, muscle, and scapula. In the same context, it will be necessary to examine the magnetic flux density reached into the lungs, which should be attenuated as a function 
medRxiv preprint doi: https://doi.org/10.1101/2021.05.21.21256456; this version posted May 25, 2021. The copyright holder for this preprint (which was not certified by peer review) is the author/funder, who has granted medRxiv a license to display the preprint in perpetuity. It is made available under a CC-BY-NC-ND 4.0 International license .

May 21th 2021

Finally, while there is a consensus that repetitive magnetic stimulation is helpful in 399 the non-invasive modulation of brain neural activity in humans, the use of similar interventions in other regions of the human body is still controversial. Besides such a

401 limitation, here we found the experimental correlation of LF-ThMS variables: magnetic 402 flux density, frequency, and temperature with SpO2 levels in 17 COVID-19 patients, five 403 of them in a single-blind, sham-controlled, crossover study.

\section{Perspectives}

Although the increased SpO2 levels may be attributed to the altered perfusion consequent to warming or the impact of magnetic factors inactivating the SARS-CoV-2 virus, at this moment, these are only speculations. Therefore, future studies will be necessary to examine the physiological mechanisms of these significant correlations.

Besides previous studies suggest that magnetic stimulation could be helpful in chronic obstructive pulmonary disease [36] and phrenic nerve activation [37], future

411 studies examining this issue by using the LF-ThMS in humans or animal preparations

412 will also be necessary. Other future perspectives include developing wearable and 413 portable devices for LF-ThMS, combined with oximeters and respiratory magnetograms 414 [38]. Such devices could help examine in more detail respiratory improvements after the 415 thoracic LF-ThMS in COVID-19 patients.

417 is instead designed to examine the hypothesis that LF-ThMS could be helpful to 418 increase SpO2 levels in COVID-19 patients in a short range from 0 to 30 minutes. In this 419 context, our findings are relevant because they could motivate future randomized clinical 420 trials to examine whether the LF-ThMS could be helpful as a potential therapy. 
medRxiv preprint doi: https://doi.org/10.1101/2021.05.21.21256456; this version posted May 25, 2021. The copyright holder for this preprint (which was not certified by peer review) is the author/funder, who has granted medRxiv a license to display the preprint in perpetuity. It is made available under a CC-BY-NC-ND 4.0 International license.

May 21th 2021

\section{Conclusions}

We conclude that our findings are relevant at this stage, mainly because they

424 provide evidence that 30 minutes of LF-ThMS on the dorsal thorax at 100 to $118 \mathrm{~Hz}$,

42510.5 to $13.1 \mathrm{mT}$ (105 to 131 Gauss), and 27.5 to $44{ }^{\circ} \mathrm{C}$ is safe in COVID-19 patients. We

426 also conclude that the LF-ThMS variables (frequency, magnetic flux density, and

427 temperature) exhibit a statistically significant correlation with SpO2 levels in the time

428 range of 30 minutes, showing that the LF-ThMS significantly increases peripheral

429 oxygen saturation levels in COVID-19 patients.

430

431

432

433

434

435

436

437

438

439

440

441

442

443 
medRxiv preprint doi: https://doi.org/10.1101/2021.05.21.21256456; this version posted May 25, 2021. The copyright holder for this preprint (which was not certified by peer review) is the author/funder, who has granted medRxiv a license to display the preprint in perpetuity. It is made available under a CC-BY-NC-ND 4.0 International license .

May 21th 2021

\section{References}

1. Babaei F, Mirzababaei M, Nassiri-Asl M, Hosseinzadeh H. Review of registered clinical trials for the treatment of COVID-19. Drug Dev Res. 2020;(ddr.21762). doi:10.1002/ddr.21762

2. Haneef K, Asghar MU, Ali A. Novel immunogenomic insights of corona virus disease (COVID-19): Available potential immunotherapeutics, current challenges, immune cell recognition and ongoing managerial strategies. Biomed Res Ther. with COVID-19: a systematic review. Infection Prevention in Practice. 2020;2(3):100061.

4. Chen P-L, Lee N-Y, Cia C-T, Ko W-C, Hsueh P-R. A review of treatment of Coronavirus disease 2019 (COVID-19): Therapeutic repurposing and unmet clinical needs. Front Pharmacol. 2020;11:584956.

5. Daou F, Abou-Sleymane G, Badro DA, Khanafer N, Tobaiqy M, Al Faraj A. The history, efficacy, and safety of potential therapeutics: A narrative overview of the complex life of COVID-19. Int J Environ Res Public Health. 2021;18(3):955.

6. Gálvez-Romero JL, Palmeros-Rojas O, Real-Ramírez FA, et al. Cyclosporine A plus low-dose steroid treatment in COVID-19 improves clinical outcomes in patients with moderate to severe disease: A pilot study. J Intern Med. 2020;(joim.13223). doi:10.1111/joim.13223 and anti-inflammatory drugs for COVID-19. Drug Discov Today. 2021;26(1):229239. 
medRxiv preprint doi: https://doi.org/10.1101/2021.05.21.21256456; this version posted May 25, 2021. The copyright holder for this preprint (which was not certified by peer review) is the author/funder, who has granted medRxiv a license to display the preprint in perpetuity. It is made available under a CC-BY-NC-ND 4.0 International license .

May 21th 2021

8. Di Lazzaro V, Capone F, Apollonio F, et al. A consensus panel review of central nervous system effects of the exposure to low-intensity extremely low-frequency magnetic fields. Brain Stimul. 2013;6(4):469-476.

9. Robertson JA, Théberge J, Weller J, Drost DJ, Prato FS, Thomas AW. Lowfrequency pulsed electromagnetic field exposure can alter neuroprocessing in humans. J R Soc Interface. 2010;7(44):467-473.

10. Cook CM, Thomas AW, Keenliside L, Prato FS. Resting EEG effects during exposure to a pulsed ELF magnetic field. Bioelectromagnetics. 2005;26(5):367376.

11. Rickaby DA, Fehring JF, Johnston MR, Dawson CA. Tolerance of the isolated perfused lung to hyperthermia. J Thorac Cardiovasc Surg. 1991;101(4):732-739.

12. Cowen ME, Howard RB, Mulvin D, Dawson CA, Johnston MR. Lung tolerance to hyperthermia by in vivo perfusion. Eur J Cardiothorac Surg. 1992;6(4):167-172; discussion 173.

13. Cohen M. Turning up the heat on COVID-19: heat as a therapeutic intervention. F1000Res. 2020;9:292.

14. Dieing A, Ahlers O, Hildebrandt B, et al. The effect of induced hyperthermia on the immune system. Prog Brain Res. 2007;162:137-152.

15. Peer AJ, Grimm MJ, Zynda ER, Repasky EA. Diverse immune mechanisms may contribute to the survival benefit seen in cancer patients receiving hyperthermia. Immunol Res. 2010;46(1-3):137-154.

16. Sen A, Khona D, Ghatak S, et al. Electroceutical fabric lowers zeta potential and eradicates Coronavirus infectivity upon contact. ChemRxiv. Published online 2020. doi:10.26434/chemrxiv.12307214.v1 
medRxiv preprint doi: https://doi.org/10.1101/2021.05.21.21256456; this version posted May 25, 2021. The copyright holder for this preprint (which was not certified by peer review) is the author/funder, who has granted medRxiv a license to display the preprint in perpetuity. It is made available under a CC-BY-NC-ND 4.0 International license .

May 21th 2021

17. Yap TF, Liu Z, Shveda RA, Preston DJ. A predictive model of the temperaturedependent inactivation of coronaviruses. Appl Phys Lett. 2020;117(6):060601.

18. Ramirez FE, Sanchez A, Pirskanen AT. Hydrothermotherapy in prevention and treatment of mild to moderate cases of COVID-19. Med Hypotheses.

19. Sigman SA, Mokmeli S, Monici M, Vetrici MA. A 57-year-old African American man with severe COVID-19 pneumonia who responded to supportive photobiomodulation therapy (PBMT): First use of PBMT in COVID-19. Am J Case

20. Guibert R, Guibert B. Combined thermotherapy and electrotherapy technique. 1994;number 5,315,994.

21. Zee J. Heating the Patient: A Promising Approach? Ann. Oncol. 2002;13(8):11731184.

22. Wust $P$, Hildebrandt B, Sreenivasa G, et al. Hyperthermia in combined treatment of cancer. Lancet Oncol. 2002;3(8):487-497.

23. Chang D, Lim M, Goos JACM, et al. Biologically targeted magnetic hyperthermia: Potential and limitations. Front Pharmacol. 2018;9:831.

514 25. Chan JF-W, Kok K-H, Zhu Z, et al. Genomic characterization of the 2019 novel human-pathogenic coronavirus isolated from a patient with atypical pneumonia after visiting Wuhan. Emerg Microbes Infect. 2020;9(1):221-236. 
medRxiv preprint doi: https://doi.org/10.1101/2021.05.21.21256456; this version posted May 25, 2021. The copyright holder for this preprint (which was not certified by peer review) is the author/funder, who has granted medRxiv a license to display the preprint in perpetuity. It is made available under a CC-BY-NC-ND 4.0 International license .

May 21th 2021

26. Huang Y, Yang C, Xu X-F, Xu W, Liu S-W. Structural and functional properties of SARS-CoV-2 spike protein: potential antivirus drug development for COVID-19. Acta Pharmacol Sin. 2020;41(9):1141-1149.

27. Min $Y-Q$, Mo $Q$, Wang J, Deng $F$, Wang $H$, Ning $Y$-J. SARS-CoV-2 nsp1: Bioinformatics, potential structural and functional features, and implications for drug/vaccine designs. Front Microbiol. 2020;11:587317.

28. Yuan S, Peng L, Park JJ, et al. Nonstructural protein 1 of SARS-CoV-2 is a potent pathogenicity factor redirecting host protein synthesis machinery toward viral RNA. Mol Cell. 2020;80(6):1055-1066.e6.

29. Qiao B, Olvera de la Cruz M. Enhanced binding of SARS-CoV-2 spike protein to receptor by distal polybasic cleavage sites. ACS Nano. 2020;14(8):10616-10623.

30. Kettleson EM, Ramaswami B, Hogan CJ Jr, et al. Airborne virus capture and inactivation by an electrostatic particle collector. Environ Sci Technol. 2009;43(15):5940-5946.

31. Leung WWF, Sun Q. Electrostatic charged nanofiber filter for filtering airborne novel coronavirus (COVID-19) and nano-aerosols. Sep Purif Technol. 2020;250(116886):116886.

32. Terunuma H. Potentiating Immune System by Hyperthermia. In: Hyperthermic Oncology from Bench to Bedside. Springer Singapore; 2016:127-135.

33. Tydings C, Sharma KV, Kim A, Yarmolenko PS. Emerging hyperthermia applications for pediatric oncology. Adv Drug Deliv Rev. 2020;163-164:157-167.

34. Haji Abdolvahab M, Moradi-Kalbolandi S, Zarei M, Bose D, Majidzadeh-A K, Farahmand L. Potential role of interferons in treating COVID-19 patients. Int Immunopharmacol. 2021;90(107171):107171. 
medRxiv preprint doi: https://doi.org/10.1101/2021.05.21.21256456; this version posted May 25, 2021. The copyright holder for this preprint (which was not certified by peer review) is the author/funder, who has granted medRxiv a license to display the preprint in perpetuity. It is made available under a CC-BY-NC-ND 4.0 International license .

May 21th 2021

35. Ziegler CGK, Allon SJ, Nyquist SK, et al. SARS-CoV-2 receptor ACE2 is an interferon-stimulated gene in human airway epithelial cells and is detected in specific cell subsets across tissues. Cell. 2020;181(5):1016-1035.e19.

36. Man WD-C. Magnetic stimulation for the measurement of respiratory and skeletal muscle function. Eur Respir J. 2004;24(5):846-860.

37. Similowski T, Fleury B, Launois S, Cathala HP, Bouche P, Derenne JP. Cervical magnetic stimulation: a new painless method for bilateral phrenic nerve stimulation in conscious humans. J Appl Physiol. 1989;67(4):1311-1318.

38. Dominguez-Nicolas SM, Juarez-Aguirre R, Herrera-May $A L$, et al. Respiratory 1450.

552 
medRxiv preprint doi: https://doi.org/10.1101/2021.05.21.21256456; this version posted May 25, 2021. The copyright holder for this preprint (which was not certified by peer review) is the author/funder, who has granted medRxiv a license to display the preprint in perpetuity. It is made available under a CC-BY-NC-ND 4.0 International license .

May 21th 2021

Figure legends

566 Figure 1. Electronic circuit employed in the low-field thoracic magnetic stimulation (LF567 ThMS) device. This electronic circuit modulates the intensity and frequency of the 568 alternating current producing the magnetic fields, limiting the maximum temperature to $44^{\circ} \mathrm{C}$, and the magnetic flux density up to $13.1 \mathrm{mT}$ at $118 \mathrm{~Hz}$.

Figure 2. Experimental arrangement. A. Anatomical landmarks for the positioning of the

571 LF-ThMS coils in the dorsal thorax of COVID-19 patients. The gray circle indicates the 572 anatomical landmark called the "spinous process of C7" or "vertebra prominens". B-D.

573 Gradual increase (every $5 \mathrm{~min}$ ) from 0 to 30 minutes of pulsed stimulus frequency, 574 magnetic flux density, and temperature during the application of LF-ThMS to COVID-19 575 patients. The stimulation consisted of applying LF-ThMS for 30 minutes on the dorsal 576 aspect of the thorax.

577 Figure 3. Comparative results obtained from the sham-controlled study and the real LF-

578 ThMS intervention. A. Peripheral oxygen saturation (SpO2) levels versus time during the 579 sham stimulation for five COVID-19 patients. Blue circles represent the grand average of 580 these SpO2 levels B. SpO2 levels versus time during the LF-ThSM stimulation. The 581 green triangles represent the grand average of SpO2 values during the real LF-ThSM in 582 the same five patients that received sham stimulation in A. The orange symbols illustrate 583 the grand average SpO2 levels in 12 COVID-19 patients versus time during a single session of LF-ThMS. The green and gray circles (raw data) show the SpO2 values 585 obtained for all the patients (every 5 minutes) versus the time in minutes. A statistically 586 significant correlation ( $p<0.001$, Pearson's product-moment correlation) was found for 587 "SpO2 values" versus "stimulation time" during real LF-ThMS but not during sham 588 stimulation. 
medRxiv preprint doi: https://doi.org/10.1101/2021.05.21.21256456; this version posted May 25, 2021. The copyright holder for this preprint (which was not certified by peer review) is the author/funder, who has granted medRxiv a license to display the preprint in perpetuity. It is made available under a CC-BY-NC-ND 4.0 International license .

May 21th 2021

Figure 4. The same as Figure 3B, but for the correlation between SpO2 levels and the variables related to the real LF-ThMS applied to 17 COVID-19 patients. The Pearson's correlation coefficients $(r)$, degrees of freedom $(D F)$, and $p$ values $(p<0.001)$ are shown

592 above each graph.

593 Tables

594 Table 1. Variables associated with the LF-ThMS (frequency, magnetic flux density, 595 temperature) and the mean SpO2 levels in 17 COVD-19 patients.

596 Table 2. One way repeated measures ANOVA for the SpO2 values of 17 COVID-19 597 patients in control conditions (0 minutes) and during the LF-ThMS at 10, 15, 20, 25, and 59830 minutes. The Bonferroni t-test was used for multiple comparisons versus the control 599 group.

600 Table 3. Follow-up on the SpO2 values for all the patients after the LF-ThMS. Six 601 months after the LF-ThMS intervention, the patients reported no adverse events, and 602 they exhibited normal SpO2 levels.

603

604

605

606

607

608

609

610 
medRxiv preprint doi: https://doi.org/10.1101/2021.05.21.21256456; this version posted May 25, 2021. The copyright holder for this preprint (which was not certified by peer review) is the author/funder, who has granted medRxiv a license to display the preprint in perpetuity.

It is made available under a CC-BY-NC-ND 4.0 International license .

May 21th 2021 


\section{Dorsal aspect of the thorax}
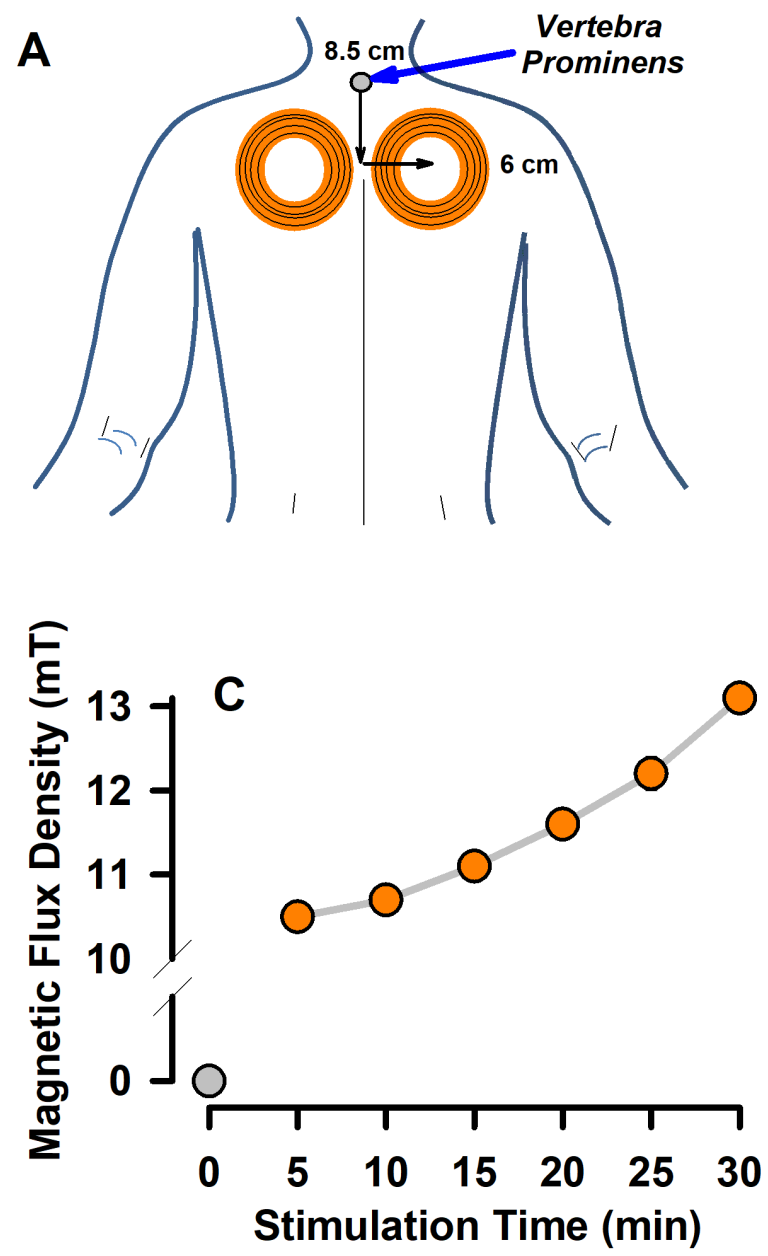

Low-Field

Thoracic Magnetic Stimulation (LF-ThMS)
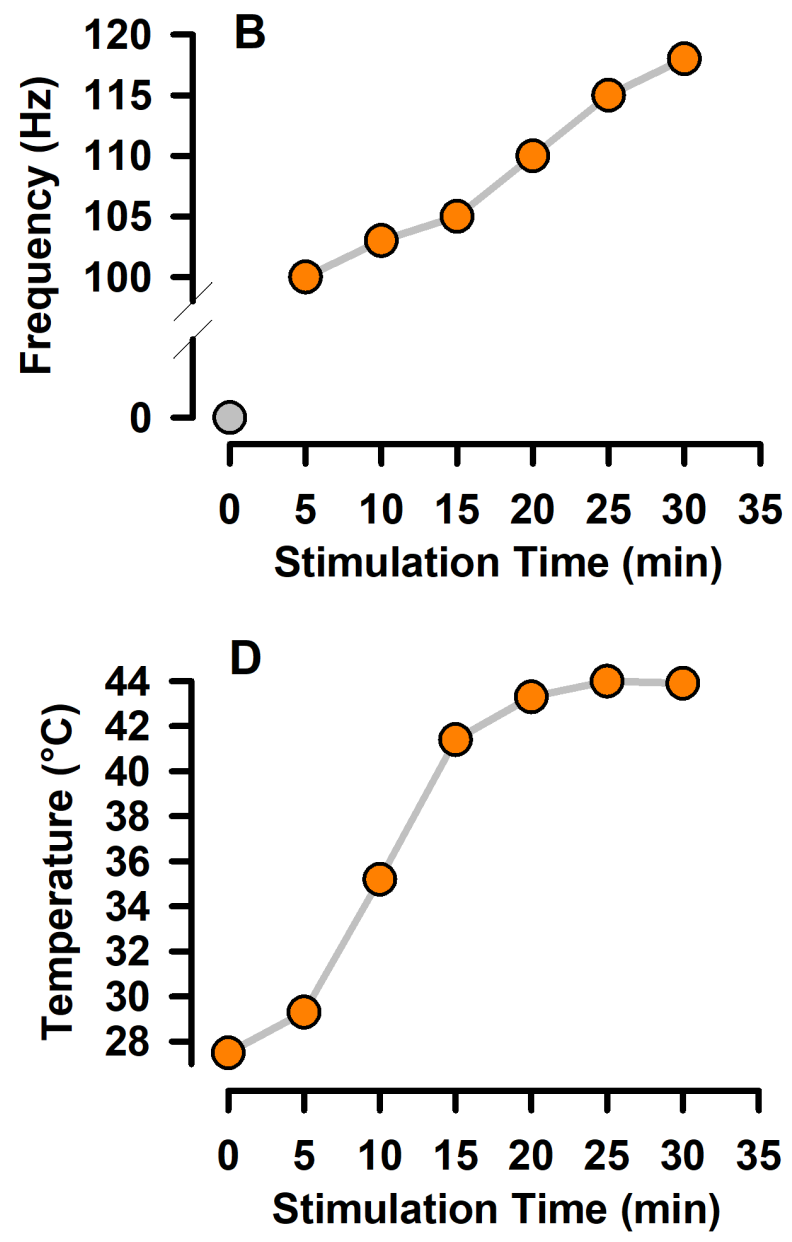
medRxiv preprint doi: https://doi.org/10.1101/2021.05.21.21256456; this version posted May 25, 2021. The copyright holder for this preprint (which was not certified by peer review) is the author/funder, who has granted medRxiv a license to display the preprint in perpetuity. It is made available under a CC-BY-NC-ND 4.0 International license .

May 21th 2021
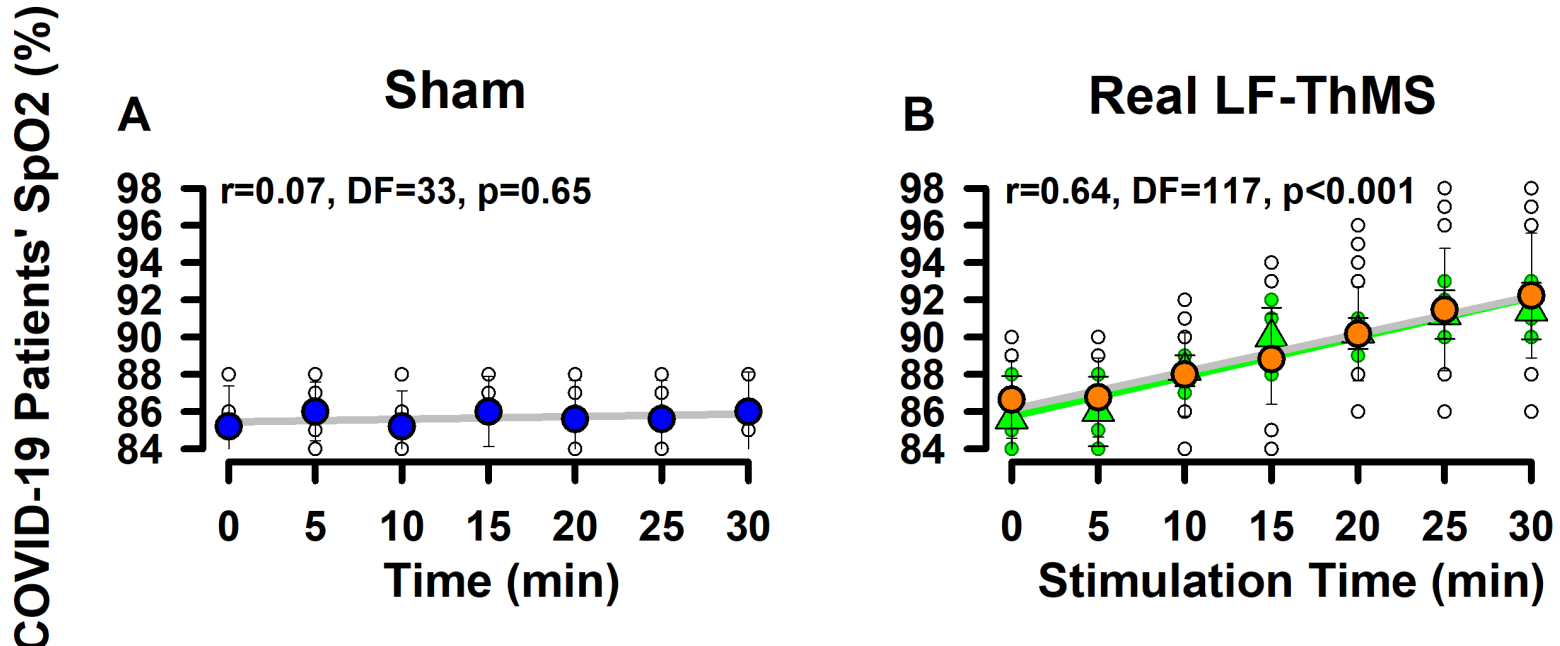
medRxiv preprint doi: https://doi.org/10.1101/2021.05.21.21256456; this version posted May 25, 2021. The copyright holder for this preprint (which was not certified by peer review) is the author/funder, who has granted medRxiv a license to display the preprint in perpetuity. It is made available under a CC-BY-NC-ND 4.0 International license .

May 21th 2021

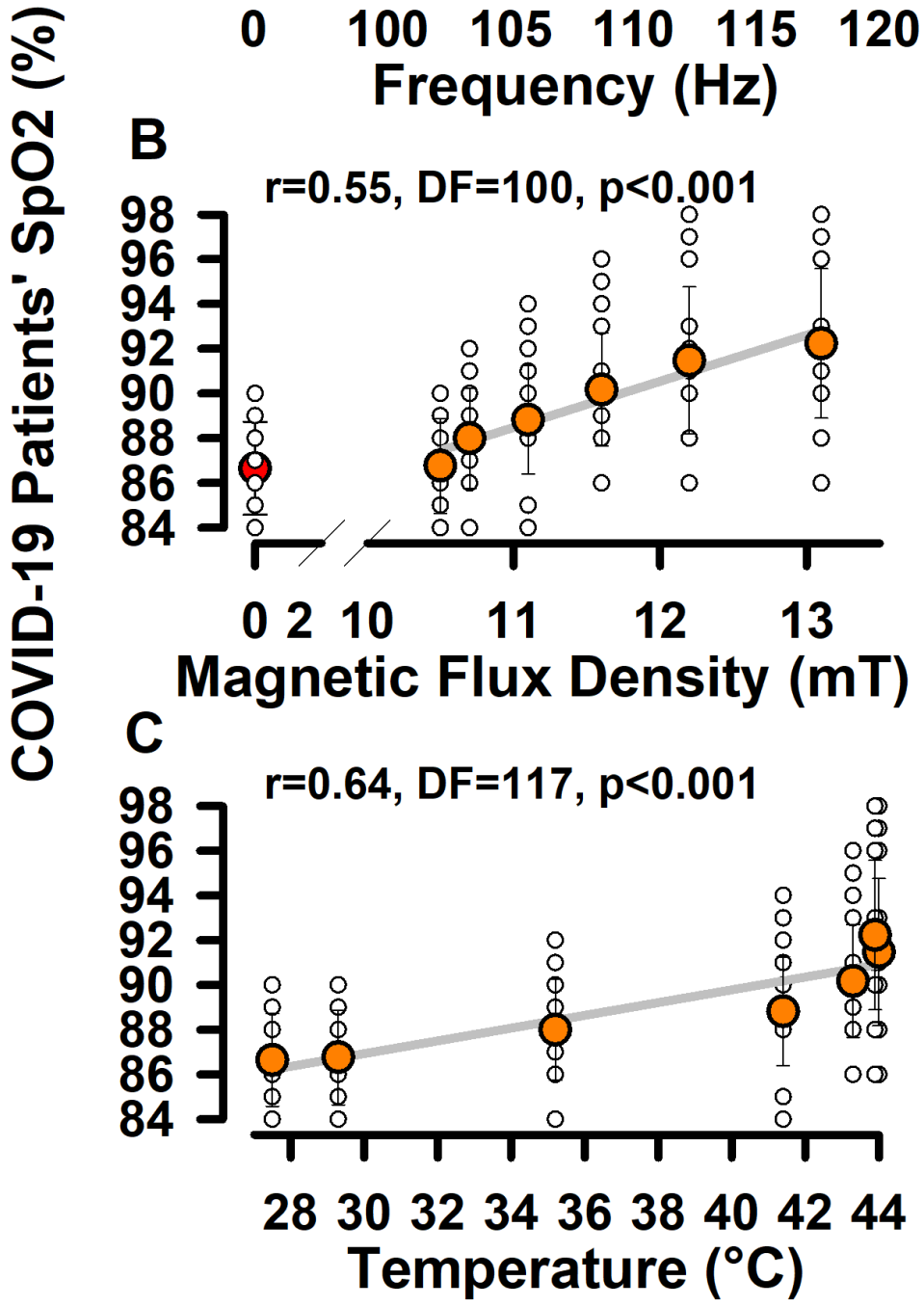


medRxiv preprint doi: https://doi.org/10.1101/2021.05.21.21256456; this version posted May 25, 2021. The copyright holder for this preprint (which was not certified by peer review) is the author/funder, who has granted medRxiv a license to display the preprint in perpetuity. It is made available under a CC-BY-NC-ND 4.0 International license.

May 21th 2021

656

657

\begin{tabular}{cccccc}
\hline $\begin{array}{c}\text { Time } \\
(\mathbf{m i n})\end{array}$ & $\begin{array}{c}\text { Frequency } \\
\mathbf{( H z )}\end{array}$ & $\begin{array}{c}\text { Magnetic } \\
\text { flux density } \\
(\mathbf{m T})\end{array}$ & $\begin{array}{c}\text { Temperature } \\
{ }^{\circ} \mathbf{C}\end{array}$ & $\begin{array}{c}\text { SpO2 (\%) } \\
\text { mean } \pm \text { SD }\end{array}$ & $\begin{array}{c}\text { Number } \\
\text { of } \\
\text { patients }\end{array}$ \\
\hline 0 & 0 & 0 & $27.5 \pm 0.2$ & $86.6 \pm 2.2$ & 17 \\
5 & 100 & $10.5 \pm 0.01$ & $29.3 \pm 0.07$ & $86.7 \pm 2.0$ & 17 \\
10 & 103 & $10.7 \pm 0.04$ & $35.2 \pm 0.08$ & $88.0 \pm 2.1$ & 17 \\
15 & 105 & $11.1 \pm 0.12$ & $41.4 \pm 0.3$ & $88.8 \pm 2.2$ & 17 \\
20 & 110 & $11.6 \pm 0.02$ & $43.3 \pm 0.2$ & $90.1 \pm 2.4$ & 17 \\
25 & 115 & $12.2 \pm 0.2$ & $44 \pm 0.05$ & $91.4 \pm 2.5$ & 17 \\
30 & 118 & $13.1 \pm 0.15$ & $43.9 \pm 0.01$ & $92.2 \pm 3.2$ & 17 \\
\hline
\end{tabular}

658 
medRxiv preprint doi: https://doi.org/10.1101/2021.05.21.21256456; this version posted May 25, 2021. The copyright holder for this preprint (which was not certified by peer review) is the author/funder, who has granted medRxiv a license to display the preprint in perpetuity. It is made available under a CC-BY-NC-ND 4.0 International license.

May 21th 2021

675

\begin{tabular}{ccccc}
\hline Comparison & Diff of Means & $\mathbf{t}$ & $\mathbf{P}$ & Significance \\
\hline SpO2 (0 min) vs. SpO2 (30 min) & 5.588 & 6.655 & $<0.001$ & Yes \\
SpO2 (0 min) vs. SpO2 (25 min) & 4.824 & 5.745 & $<0.001$ & Yes \\
SpO2 (0 min) vs. SpO2 (20 min) & 3.529 & 4.203 & $<0.001$ & Yes \\
SpO2 (0 min) vs. SpO2 (15 min) & 2.176 & 2.592 & 0.065 & No \\
SpO2 (0 min) vs. SpO2 (10 min) & 1.353 & 1.611 & 0.66 & No \\
SpO2 (0 min) vs. SpO2 $(5 \mathrm{~min})$ & 0.118 & 0.14 & 1 & No \\
\hline
\end{tabular}

676

677 
medRxiv preprint doi: https://doi.org/10.1101/2021.05.21.21256456; this version posted May 25, 2021. The copyright holder for this preprint (which was not certified by peer review) is the author/funder, who has granted medRxiv a license to display the preprint in perpetuity. It is made available under a CC-BY-NC-ND 4.0 International license .

May 21th 2021

691

692

693

\begin{tabular}{cccccc}
\hline & $\begin{array}{c}\text { Before } \\
\text { LF-ThMS }\end{array}$ & $\begin{array}{c}\text { 30 minutes after } \\
\text { Sham Stimulus }\end{array}$ & $\begin{array}{c}\text { 30 minutes after } \\
\text { LF-ThMS }\end{array}$ & $\begin{array}{c}\text { Five days after } \\
\text { LF-ThMS }\end{array}$ & $\begin{array}{c}\text { Six months after } \\
\text { LF-ThMS }\end{array}$ \\
\hline Patients & SpO2 (\%) & SpO2 (\%) & SpO2 (\%) & SpO2 (\%) & SpO2 (\%) \\
\hline Patient 1 & 88 & - & 98 & 98 & 99 \\
Patient 2 & 86 & - & 97 & 98 & 97 \\
Patient 3 & 89 & - & 96 & 98 & 97 \\
Patient 4 & 90 & - & 97 & 99 & 99 \\
Patient 5 & 87 & - & 91 & 98 & 99 \\
Patient 6 & 90 & - & 93 & 99 & 99 \\
Patient 7 & 87 & - & 91 & 97 & 98 \\
Patient 8 & 88 & - & 93 & 98 & 98 \\
Patient 9 & 87 & - & 91 & 99 & 99 \\
Patient 10 & 86 & - & 90 & 98 & 99 \\
Patient 11 & 84 & - & 88 & 97 & - \\
Patient 12 & 83 & - & 86 & 99 & - \\
Patient 13 & 84 & 85 & 93 & 99 & - \\
Patient 14 & 85 & 86 & 90 & 99 & - \\
Patient 15 & 88 & 88 & 93 & 99 & - \\
Patient 16 & 83 & 83 & 90 & 98 & - \\
Patient 17 & 88 & 88 & 91 & 99 & $98.4 \pm 0.8$ \\
\hline & $86.6 \pm 2.2$ & $86 \pm 2.1$ & $92.2 \pm 3.2$ & $98.3 \pm 0.7$ & \\
\hline
\end{tabular}

695

696

Table 3

697

698

699

700

701

702 
medRxiv preprint doi: https://doi.org/10.1101/2021.05.21.21256456; this version posted May 25, 2021. The copyright holder for this preprint (which was not certified by peer review) is the author/funder, who has granted medRxiv a license to display the preprint in perpetuity. It is made available under a CC-BY-NC-ND 4.0 International license .

May 21th 2021

\section{Ethics and reporting}

704 We declare that all relevant ethical guidelines have been followed and ethics committee approval has been obtained. All necessary patient/participant consent has been obtained. SPIRIT-Checklist was included as a supplementary file.

\section{Acknowledgments}

We thank Prof. Robert Simpson for proofreading the English document.

\section{Data Availability Statement}

The authors confirm that all data underlying the findings are fully available without

restriction upon request. All relevant data are within the paper.

\section{Author contributions}

713 SMDN conceived the therapeutic application of magnetic stimuli in COVID-19 patients,

714 developed the first LF-ThMS prototype, and performed the experiments. EM and SMDN conceived the proof-of-concept and hypothesis of this study. EM performed the data analysis. EM designed the single-blind, sham-controlled, crossover study on 5 COVID19 patients, wrote the paper, and contributed to calibrate and improve the safeness of

718 the original LF-ThMS prototype.

\section{Funding}

720 Centro de Investigación de Micro y Nanotecnología (SMDN), National Council of

721 Science and Technology, Mexico, CONACyT Fronteras de la Ciencia \#536 (EM),

722 Cátedra Marcos Moshinsky (EM), and VIEP-PIFI-FOMES-PROMEP-BUAP-Puebla 723 (EM), Comité de Internacionalización and VIEP BUAP (EM), México.

\section{Conflict of Interest}

725 The authors declare that the research was conducted in the absence of any commercial 726 or financial relationships that could be construed as a potential conflict of interest. 